\title{
Inhibitory effects of substrate and product on the carvone biotransformation activity of Rhodococcus erythropolis
}

Jenna L. E. Morrish · Andrew J. Daugulis

Published online: 27 March 2008

(C) Springer Science+Business Media B.V. 2008

Erratum to: Biotechnol Lett

DOI 10.1007/s10529-008-9686-5

In the third sentence of the Abstract of the original, the letter ' $\mathrm{l}$ ' for 'litre' was omitted from the term 'phase 31 reactor'.

The online version of the original article can be found under doi:10.1007/s10529-008-9686-5.

J. L. E. Morrish · A. J. Daugulis ( $\square)$

Department of Chemical Engineering,

Queen's University, Kingston, ON,

Canada K7L 3N6

e-mail: andrew.daugulis@chee.queensu.ca 